\title{
The Impact of Industry 4.0 on Jobs Creation within the Small and Medium-Sized Enterprises and Family Businesses in Slovakia
}

\author{
Adriana Grenčíková, Marcel Kordoš * (1) and Vladislav Berkovič \\ Faculty of Social and Economic Relations, Alexander Dubček University in Trenčín, 91150 Trenčín, Slovakia; \\ adriana.grencikova@tnuni.sk (A.G.); vladislav.berkovic@tnuni.sk (V.B.) \\ * Correspondence: marcel.kordos@tnuni.sk; Tel.: +421-32-7400-470
}

Received: 28 July 2020; Accepted: 7 September 2020; Published: 10 September 2020

\begin{abstract}
Industry 4.0 has been creating new jobs for several years, and people are already being employed in work positions that did not exist ten years ago. Due to the speed and complexity of the changes brought about by the Fourth Industrial Revolution, it will be necessary to respond adequately and flexibly to this challenge. This research paper is devoted to the issue of Industry 4.0 outbreak into industrial enterprises, while the issue of job structure will become an increasingly urgent one. The main objective of this problem-oriented quantitative type of research is based on the analysis of the state and course of Industry 4.0 implementation process to estimate the impact of Industry 4.0 concept implementation on job creation in small and medium-sized enterprises and family businesses in Slovak Republic. A questionnaire survey in small and medium-sized enterprises in Slovak Republic was chosen as the fundamental research method. The results have shown that new technologies will increasingly displace physical labor in particular, and emerging jobs will put ever-increasing demands on human intellect. The conclusions from our findings can be the basis for the creation of educational programs not only within the workplace but also in the educational system in Slovak Republic.
\end{abstract}

Keywords: Industry 4.0; family business; employers; skills; employees; education content; Slovak industry companies

\section{Introduction}

The Fourth Industrial Revolution is a concept based on the German concept of Industry 4.0, nevertheless experts still do not completely agree on what the result from the introduction of this concept would be (Hnat and Stuchlikova 2014; Zemanova and Drulakova 2016). Krnacova and Drabik (2018) argue that industrial companies in Slovakia, represented by their management, have not taken Industry 4.0 challenges into account for a long time. So far it has been seen something like as a Western fashion trend, and the implementation of platforms such as the Internet of Things, Big Data, cloud computing operations, virtual reality, and 3D printing were not deployed in almost any domestic industrial enterprise. Jirankova et al. (2015) and Krajnakova et al. (2018a) reason that it was different story when it comes to foreign investors, especially in automotive industry and in the network of their suppliers. Recently, however, the situation has changed, and companies have become more involved in the Industry 4.0 platform. According to Mura (2019) and Dudáš and Grančay (2019) the problem remains the uncertainty as the Industry 4.0 with all its components to be gradually and successfully implemented within not only the large companies but also small and medium sized enterprises.

The presented study analyzes the impact of Industry 4.0 on Slovak small and medium sized enterprises and the current state of automation and robotics implementation in these enterprises. 
The real-status detection provides us with the information necessary for further analysis of rate development and, in particular, analysis of potential impact on labor market. Therefore, the main goal of the research, presented in the current paper, is to reveal and estimate the effect of Slovak entrepreneurship environment being able to adopt to the current Industry 4.0 challenges. Additionally, we estimate if this change is to result in any massive outflow of workers or the emergence of new jobs. The data collected aim to bring specificity to the discussion and open up opportunities for further action by providing perspective to human resource managers at strategic employers, who are among the leading players in new trends and are key players in the implementation of future workforce strategies. For these reasons, we have been dealing with this issue for several years being the solvers of the Slovak Ministry of Education research grants Vega 1/0430/18 and Vega 1/0462/20. The object of interest of the research was the opinions of employers on the actual development in companies. In the initial phase of the research, we were focused mainly on large industrial companies, but the research gradually expanded the interest to other industries and sectors especially within the area of small and medium-sized enterprises and family businesses, along with the development of Internet, automation and robotics affecting all processes in human activities. The conducted research was focused mainly on technical problems and solutions, and there were the views being introduced in Slovakia to this issue that drew attention in a different direction to the impact on labor market and other changes being brought by. Our important research partner in this area is the company Sova Digitál, being a leader within the promotion issue of Industry 4.0 in Slovakia. The goal of the paper is by analyzing the state and course of Industry 4.0 implementation process to estimate the impact of Industry 4.0 concept implementation on job creation in small and medium-sized enterprises and family businesses in Slovak Republic. The outline of this paper features in Section 1 a short introduction to the topic of Industry 4.0 and literature review in Section 2, followed by the proposed goal and research methodology in Section 3. Finally, the results are presented in Section 4, consequently discussed in Section 5 and ended up by brief conclusions in Section 6.

\section{Literature Review}

Authors such as Cihelkova and Nguyen (2018), Hanulakova and Dano (2018) argue that technological changes in the spirit of Industry 4.0 are a response to market demands, the pressure of these requirements cannot be managed without rapid innovation and shortening the time being necessary to bring a product to market. Therefore, in this sense a successful company will be the one that will be faster. Cihelkova et al. (2020) and Zemanova (2015) declare that the implementation processes take place in parallel, and thus it is necessary to have a quality and professional team, a well-thought-out procedure, a sequence of steps that map strategic opportunities and set up the processing of a pilot innovation project. After its evaluation, the Industry 4.0 implementation program for the next period will be set. This will bring effects in terms of increasing productivity, flexibility, quality, or costs reduction. Hanulakova et al. (2019) and Kiselyova (2020) concede that at first glance, Industry 4.0 may look like production automation aimed at reducing personnel costs in particular. However, this is only a very narrow view, which does not correspond to reality. Nevima et al. (2018) contend that the implementation of Industry 4.0 principles is about unity across the entire business beyond the borders of the company by itself. Cernohlavkova et al. (2013) and Zemanova and Drulakova (2020) concur that it's about a change of mindset that should lead to a change in existing practices-and not about products that bear the "Industry 4.0 ready" label. Many authors such as Kreckova et al. (2012) and Nenckova et al. (2020) indicate that in particular, the ability to change management thinking can be a key issue. It will be a complex change of business, which represents a challenge for today's, not only manufacturing companies. According to Eurostat (2020) the fact that this is a truly fundamental change is also evidenced by the fact that the digital transformation of industry is estimated to require investments exceeding 0.7 billion EUR in Europe by 2020. Grmelova (2018a) and Jirankova (2012) dispute that the goals of implementing Industry 4.0 can be different in each company i.e., complex and partial. It can be an increase in the competitiveness of a company as such, but also an increase 
in its attractiveness within the market. A partial goal, in turn, may be the introduction of mobile or predictive maintenance, which will increase the flow of production and extend the life of machines, or increase the efficiency of the service provided ultimately leading to enhancing personalization of products placed on the market (Salama and Oláh 2019).

Fojtikova (2018) and Harakal'ova (2018) state that one of the basic aspects of Industry 4.0 is the Internet of Things issue. In the next ten years, all machines and some components in them will be able to communicate with each other. In conjunction with other technologies such as digital enterprise, intelligent robots working with humans, huge amounts of data, machine learning or elements of artificial intelligence, the production will gain the ability to be self-managed and self-organized. Lipkova and Hovorkova (2018) agree that it will be a system with decentralized management and autonomous decision-making-an intelligent factory will be created; which experts refer to as the cyber-physical system. Hnat and Sankot (2019) assert that these changes will fundamentally affect the life of human society, therefore it is necessary to expect changes in all areas of a society. On one hand, according to technological pessimists, the critical benefits of the digital revolution have already been achieved, so the effects on productivity are almost exhausted (Sadilek and Zadrazilova 2016). On the other hand, technological optimists, declare that new technologies and innovations are still at an inflection point and will soon be reflected in increased productivity and higher economic growth (Grmelova 2018b). Miklosik et al. (2019a) and Tauser et al. (2013) indicate that the fourth industrial revolution is seen as the so-called "path to an innovative economy" because the implementation of digital connectivity will not only improve efficiency but also accelerate innovation and bring new business models that could be implemented much faster.

According to Mura et al. (2017) and Haviernikova and Klucka (2019) at the end of 2016, the Slovak government also responded to the challenges of Industry 4.0 and within its resolution entitled "Concept of Smart Industry for Slovakia" it describes the current situation and requires the relevant ministries to establish a smart industry platform and develop an action plan for smart industry in Slovakia. The area where governmental support is expected is the persistently small added value issue in automotive industry in particular (MH SR-Ministry of Economy of Slovak Republic 2020). Many authors such as Bolotov and Tauser (2015) and Tupa and Vojtovic (2018) concede that research and development in the conditions of Slovak Republic is at a low level and permanently underfunded. Innovations arise outside the country and industrial companies in terms of foreign direct investing place only the production part employing mostly the unskilled labor in Slovakia. Daňo and Lesáková (2018) and Drabik and Zamecnik (2016) affirm that the action plan of smart industry in Slovakia should include significant support for research and development activities and support, in particular, investments of foreign investors in this area of operation. Helisek (2018) and Varadzin (2016) state that support for domestic innovation projects is expected to the greatest extent. The basis on which this change towards a smart industry can take place is a change in education, not for the current industry needs, but for the future industry needs. Helisek (2015) and Haviernikova and Ivanova (2018) concur that taking into account the fast speed of this industry transformation, there is emerging another challenge in which government must take an active approach, called lifelong learning. New technologies will increasingly displace physical work in particular, and new emerging jobs will put ever-increasing demands on human intellect.

Boukalova et al. (2016) and Tajtakova et al. (2019) concede that the deployment of smart industry elements will mainly affect production. Authors who publish in this area focus mainly in this direction, however, sectors such as trade, tourism or services will be significantly affected as well. Thanks to the appearance of new communication technologies, for example, tourism segment has changed significantly, where the final product becomes truly personalized to customer requirements. The sale of tickets as well as bookings were automated and digitalized, which ultimately led to an increase in sales in tourism (Fojtikova and Stanickova 2017; Ivanová and Masárová 2018). Lipkova et al. (2017) and Svarc and Grmelova (2015) reason that proponents of Industry 4.0 expect the optimized features and processes of a middle-sized company to increase revenue by several million EUR a year. An example 
of the positive effects of digitization and robotics is Siemens, which increased its production sevenfold thanks to the Industry 4.0 concept implementation and achieved $99.9966 \%$ accuracy in production processes, which is a world record within comparable companies (Krajnakova et al. 2018b; Simionescu et al. 2019; Jašková 2019). The issue of replacing the workforce with technology is becoming a much-discussed issue. According to an OECD study prepared for the German government, it is said that 500,000 jobs will be lost, but 900,000 will be created. An OECD study prepared for Slovak Republic states that every second job will undergo certain changes (OECD 2020; MH SR-Ministry of Economy of Slovak Republic 2020). Ongoing discussions on the effects of (adverse) changes on employment often lead to fundamental differences of opinion between those who expect unlimited opportunities and prospects to increase workers' productivity and liberation from physical and routine work in emerging jobs, and those who expect massive work replacement and the relocation of jobs to other countries (Sauer et al. 2019; Saroch 2015).

Sejkora (2014) and Sejkora and Sankot (2017) argue that companies expect the implementation of intelligent industry elements the most in the field of production. This expectation can be attributed, among other things, to two important factors. Zagata et al. (2019) and Sauer et al. (2018) assert that the first of them is a number of companies, where the Industry 4.0 concept application is significantly dominated by industrial production companies, for which it is natural that the implementation of intelligent industry elements will relate to their focus. According to Zagata et al. (2020) and Saroch and Famfule (2016) the second equally important factor are the other areas where companies expect to apply smart industry elements such as logistics, customer communication and administration. These areas of business activity will be those that will be most affected by Industry 4.0 in terms of employment structure. Machkova and Sato (2017) and Mura and Kljucnikov (2018) replenish that the area of development within the implementation of smart industry elements remained at the tail of interest of all companies. At the same time, experts expect that it is in the development phase that Industry 4.0 can be most helpful in several respects. Authors such as Miklosik et al. (2018) and Cajka et al. (2015) mention the following aspects of Industry 4.0 application within the research and development area: the identification of customer needs, the sensitivity of product innovations being implemented, the development time shortening, and reducing the cost of new product development.

Toth et al. (2019) and Sadilek and Zadrazilova (2015) argue that changes related to the implementation of Industry 4.0 concept should have a positive effect on increasing the competitiveness of companies, increasing production flexibility, i.e., generally gaining a better position of companies on the market as a result of greater process efficiency in companies. The expected positive impacts can be summarized as follows: higher productivity (elimination of errors and risks, production of larger quantities of products, reduction of working hours); higher flexibility (individualized products, more efficient production, wide variability in control processes); higher competitiveness (lower production costs, implementation of innovations and innovative solutions, flexible responses to fluctuations in demand); higher profitability (mass production, process optimization, lower stocks, more economical production); safety (limiting defects and errors-software, protection of workforce safety by sensors, immediate reactions and interventions); ecology (switching off unused objects, using so-called "green" solutions, renewable energy sources, and so on (Jirankova and Hnat 2012; Miklosik et al. 2019b; Krajnakova and Vojtovic 2017 and Machkova 2013).

Small and medium-sized enterprises (SMEs) in OECD countries represent more than $95 \%$ of the total number of all enterprises, with their share in employment averaging around $75 \%$ and their share in GDP up to 80\% (OECD 2020). Okreglicka et al. (2017) and Belas et al. (2020) assert that in Slovak Republic, the quantitative share of small and medium-sized enterprises is comparable to developed countries, while their share in employment in 2016 was more than $70 \%$. According to MH SR-Ministry of Economy of Slovak Republic (2020) with its GDP generation, the small and medium-sized enterprise sector represents approximately $3 / 5$ of the total production volume in terms of GDP. Maitah and Smutka (2019) and Lipkova (2017) affirm that within the developed economies, this category of enterprises is considered to be the most flexible, most efficient, most progressive and 
thus also the most important part of the economy. For this reason, the countries of the European Union, but also other developed countries such as the USA and Japan, pay maximum attention to the issue of small and medium-sized enterprises and constantly take measures for its development. In these countries, support for small and SMEs have become an important part of the overall economic strategy over the last 30 years (Kreckova et al. 2016; Saroch and Smejkal 2018; Zadrazilova 2013).

The role of human in Industry 4.0 is a crucial issue. According to Di Nardo et al. (2020a) human help is important not only to collect data and to turn them into added-value information but also the cognition - the devices can be just a support to the decision-making. So the goal of automation will be to provide devices that will collect data and aggregate them and then provide them, in the most user-friendly way, to the person in charge of making appropriate decisions based on the data available. This support is given by the HMI (Human-machine Interface). The work of the machine, therefore, is submitted to human judgment: where this is positive, the approved action becomes a new stable operating model for the machine. The primary function of the worker will be to lead a production strategy and manage the implementation thereof the self-organizing production processes.

Di Nardo et al. (2020b) argue that a safety management system, in order to be proactive, must be able to measure performance and make future forecasts, so it requires a series of precise and numerous data. In this perspective, the paradigm of Industry 4.0 is able to collect, through a dense network of sensors, a quantity of data and is able to manage and analyze them, allowing the forecast of possible accident scenarios. For example, the support of sensors and new technologies allows the detection of a series of data necessary to make predictions as reliable as possible on the health status of the equipment that leads to targeted interventions.

Within the Internet of things also other issues can be mentioned. Fraga-Lamas et al. (2017) concede that the Internet of Trains paradigm holds the promise that rail systems can leapfrog interoperability, safety, and cyber security issues, while modernizing rapidly. It refers to the use of networks of intelligent on-board devices connected to cloud-based applications to improve communications and control systems. The same network that strengthens safety has enough capacity to deliver enhanced data that serves a variety of applications across the rail system to reduce costs and improve operations.

The relationship between knowledge sharing and incentives was further supported by studies of Slovak authors such as Ližbetinová et al. (2020), Stachová et al. (2020) and Blštáková et al. (2020) who found that there were significant changes in the stimulus system that encouraged individuals to share their knowledge, especially through technology. The forthcoming Fourth Industrial Revolution provides comprehensive systems and tools aimed at promoting information sharing at the individual, team, and organization levels, as well as at a cluster level. Organizations are now realizing the fact that knowledge sharing is important because it provides a link between individuals and organizations. It is the transfer of the knowledge that individuals have that transform to the organizational level into economic and competitive value for organizations. Organizations recognize the need to focus on motivating individuals to share knowledge, as these are confidential and inextricably linked to human egos and commitment and do not flow easily through the organization.

\section{The Goal and Research Methods}

The main goal of the research is based on the analysis of the state and course of Industry 4.0 implementation process to estimate the impact of Industry 4.0 concept implementation on job creation in small and medium-sized enterprises in Slovak Republic. To find out the current state and expectations of employers in the industry, a survey of opinions has been chosen and the questionnaire survey was used as a principal method. The questionnaire was created by the research team within the Vega 1/0430/18 project and subsequently distributed to the respondents through Alexander Dubček University students. The results were collected and initially processed by means of the GoogleForms questionnaire. The survey took place in the months of October-November 2019. The questionnaire was created and then implemented via the Internet as a website. Respondents who received an e-mail invitation could connect to this page via the Internet and fill in individual questions electronically. 
Through the questionnaire, industrial companies in Slovakia were contacted by an e-mail, in person or by telephone and asked them to comment on individual questions of the questionnaire. The questionnaire sample size has been set within the Vega project framework. The outputs from the second part of our pilot project dealing with the Industry 4.0 concept implementation issue are presented in this paper. In terms of this particular survey no hypothesis was set. The structure of questions within the questionnaire has been outlined according to the Vega project settings. Through a questionnaire, also students personally addressed companies in Slovakia and asked them to fill in the questionnaire and comment the particular items. The original condition, or rather the intention, to select a sample of respondents was that the company is operating in the field of industry. Due to the fact that this condition could not have been met, also information from areas other than industry was obtained, which was beneficial in the final investigation and therefore these companies were not excluded from the sample being assessed. Every company that received an invitation to participate in the research had to be registered in the Commercial Register of Slovak Republic.

Within the division of the questionnaire, the often used criterion is the division according to the size of a company. To make it clear, the categories for a micro-enterprise/family business, small, medium-sized and large enterprise were defined according to the division of the Statistical Office of Slovak Republic. Based on the mentioned issue the division is defined as follows: companies with up to 9 employees as family businesses, enterprises from 10-49 as small enterprises, enterprises from 50-249 as medium-sized enterprises and enterprises from 250 employees as large enterprises. Within this breakdown for simplification, the turnover of the company has not been take into account, also because the research deals with the expected changes within the number and qualification of employees in companies. The questionnaire was distributed to 250 companies and answered by 229 companies. The questionnaire was titled "The Impact of Industry 4.0 on Job Creation" and contained 12 questions. The aim was to find out the current state of knowledge of the concept of industry 4.0 in industrial enterprises in Slovak Republic, the degree of its application, to determine the current structure of production and non-production workers and the view of these companies on the future needs of workers. It has been managed to address large companies in particular through a questionnaire survey, however the difference is not so significant compared to small and medium-sized enterprises, highlighting that Industry 4.0 is becoming known relatively quickly. This issue is considered important because family businesses and small and medium-sized enterprises (SMEs) are an integral part of the whole spectrum of companies in most countries in the world.

\section{Research Results and Findings}

For the main area of operation, there were chosen activities based on the industry qualification within the area of the company. However, originally, the aim was to examine just industrial companies, but the questionnaires came back from other companies' areas, pointing out to the fact that the implementation of new Industry 4.0 communication platforms affects all areas of a society. For this reason, a decision has been made to include those answers into the research results. The final spectrum of operations regarding the participating companies into the conducted survey is illustrated in Figure 1 and Table 1. 
Table 1. The main area of the company's operation.

\begin{tabular}{|c|c|c|c|c|c|}
\hline The Main Area of Company'S Operation & All Enterprises & Family Businesses & Small Business & Medium Business & Large Company \\
\hline no answer & 68 & 29 & 20 & 9 & 10 \\
\hline CA Production of food, beverage and tobacco products & 17 & 5 & 4 & 4 & 4 \\
\hline CB Production of textiles, clothing, leather and leather products & 4 & & & 2 & 2 \\
\hline CC Production of wooden and paper products, printing & 8 & 3 & 2 & 1 & 2 \\
\hline $\begin{array}{l}\text { CF Production of basic pharmaceutical products and } \\
\text { pharmaceutical preparations }\end{array}$ & 1 & & & & 1 \\
\hline $\begin{array}{l}\text { CG Production of rubber and plastic products and other } \\
\text { non-metallic mineral products }\end{array}$ & 19 & 1 & 3 & 4 & 11 \\
\hline CI Production of computer, electronic and optical products & 10 & & 3 & 1 & 6 \\
\hline CJ Electrical equipment production & 14 & & 2 & 1 & 11 \\
\hline CK Production of machinery and other equipment & 8 & & 1 & 3 & 4 \\
\hline CL Transport equipment production & 8 & 1 & & & 7 \\
\hline $\begin{array}{l}\text { CM Other production, repair and installation of machinery and } \\
\text { equipment }\end{array}$ & 20 & 9 & 3 & 4 & 4 \\
\hline E-Water supply; wastewater treatment and disposal & 1 & & & 1 & \\
\hline $\mathrm{F}$-Construction & 4 & 2 & 1 & 1 & \\
\hline $\mathrm{H}$-Transport and storage & 3 & 2 & 1 & & \\
\hline $\begin{array}{l}\mathrm{CH} \text { Production of metals and metal structures except machinery } \\
\text { and equipment }\end{array}$ & 27 & 6 & 10 & 4 & 7 \\
\hline I-Accommodation and food services/catering & 1 & 1 & & & \\
\hline $\mathrm{L}-$ Real estate activities & 1 & & 1 & & \\
\hline S-Other activities & 12 & 2 & 5 & 3 & 2 \\
\hline
\end{tabular}




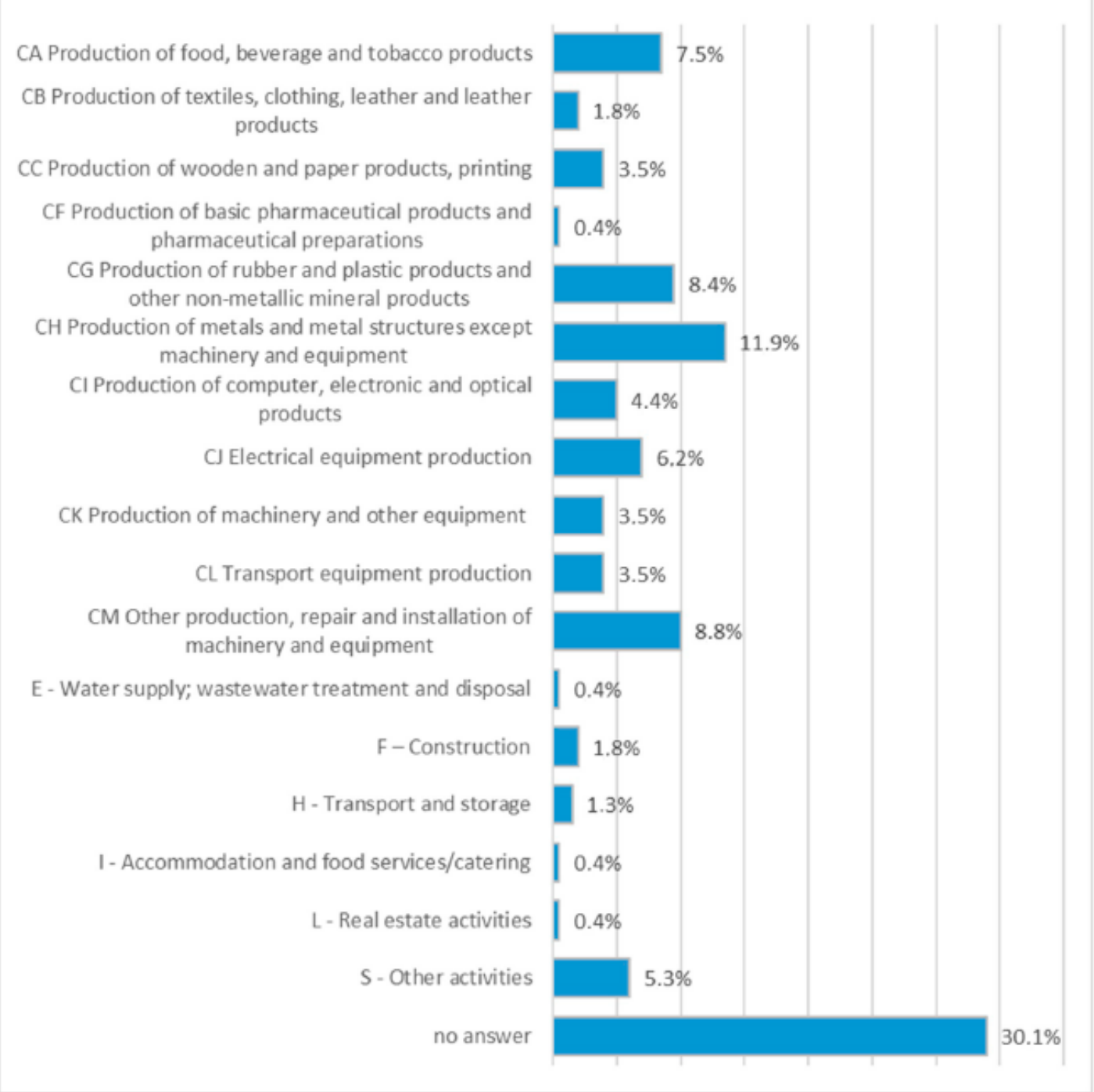

Figure 1. The main area of the company's operation.

As the processes regarding the Industry 4.0 concept implementation take place in companies in parallel and systematically, it was necessary to find out the opinion of addressed companies on the state of their Industry 4.0 implementation process. The question asked by the respondents in the questionnaire survey was as follows: Does your company deal with the of elements of smart industry implementation? The survey results show that, compared to the previous year 2018, it can be observed a significant shift in the Industry 4.0 implementation process. In 2018, out of the total sample, $23.5 \%$ companies expressed that they were intensively implementing the Industry 4.0 concept and $26.5 \%$ that they were implementing the smart industry elements, which together accounted for $50 \%$. According to Figure 2, in 2019, a significant shift can be seen in large enterprises, it is up to $84.5 \%$ of respondents; in medium-sized enterprises it is $71.1 \%$ of respondents and in small enterprises it is $62.4 \%$ of respondents. However, the lagging group are family businesses with up to 9 employees. Either way, it can be considered a positive trend that $39.3 \%$ of them are already starting to implement the smart industry elements. It is anticipated that next year their interest in implementing the smart industry elements will increase again. It is considered this a necessary trend. It is estimated the overall increase in interest in this issue to be around 30\% per year, due to the diversity of companies it is not possible to quantify it precisely. 


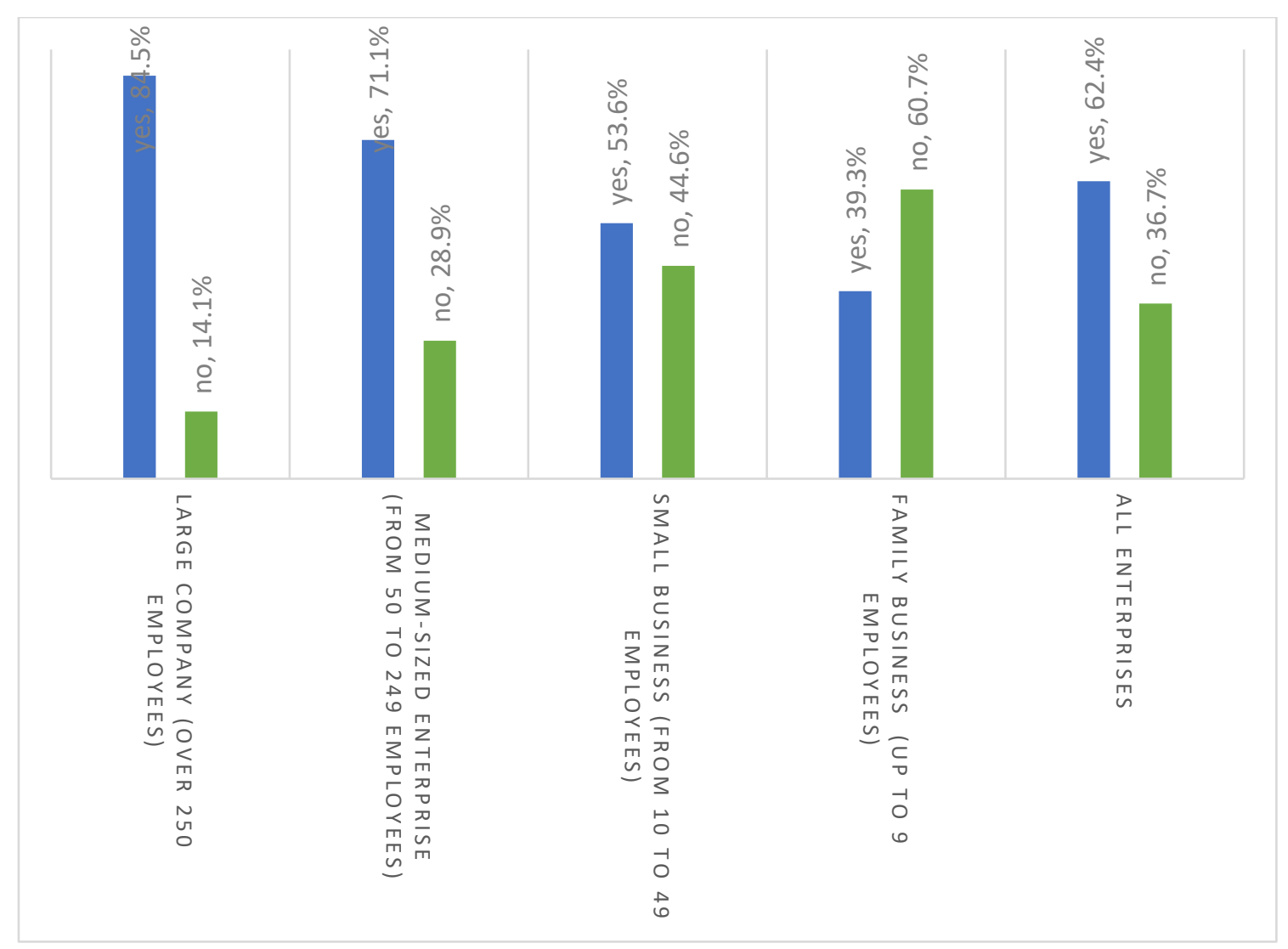

Figure 2. Industry 4.0 implementation rate in 2019.

As the goals of the implementation of Industry 4.0 may be different in each company, complex and partial, the next step in the research was focused on departments initiating the intelligent industry elements implementation in companies. It is clear from Figure 3 that the question "Which department initiates the deployment of smart industry elements" could not be answered to a significant extent, especially by family businesses and small enterprises. Their share without a specific answer was about a quarter. As the company grows, so does the level of knowledge about implementing the Industry 4.0 concept. While for medium-sized companies almost one-sixth of respondents do not know or do not have a department dealing with Industry 4.0, for large companies it is only less than three percent. On the contrary, the degree of involvement of the ownership structure in company decreases with the increasing size of a company. While in case of family businesses and small enterprises the intelligent industry elements implementation is solely the agenda of the ownership, in case of medium-sized enterprises this ratio is visibly changing in favor of the company's management. When it comes to majority of companies, the implementation of Industry 4.0 elements in almost thirty percent of cases it is the agenda of the company's management, followed by the ownership structure managing just over twenty percent. In all the surveyed companies, the other named departments are not significantly involved in initiating the implementation of smart industry elements, their degree of involvement is, as assumed, rather related to the partial fulfillment of tasks within the Industry 4.0 implementation.

Not only in case of small and medium-sized enterprises, when introducing the elements of Industry 4.0 concept into production, the greatest impacts are expected in the area of employment. Therefore, the next step in the research was focused on the question of how the smart industry elements implementation will affect the number of employees in the company. Figure 4 shows in which areas of a company the Industry 4.0 will affect the number of employees. The overall results show that indeed the most significant changes in jobs are expected in production processes, but also in administration, logistics and online sales. 


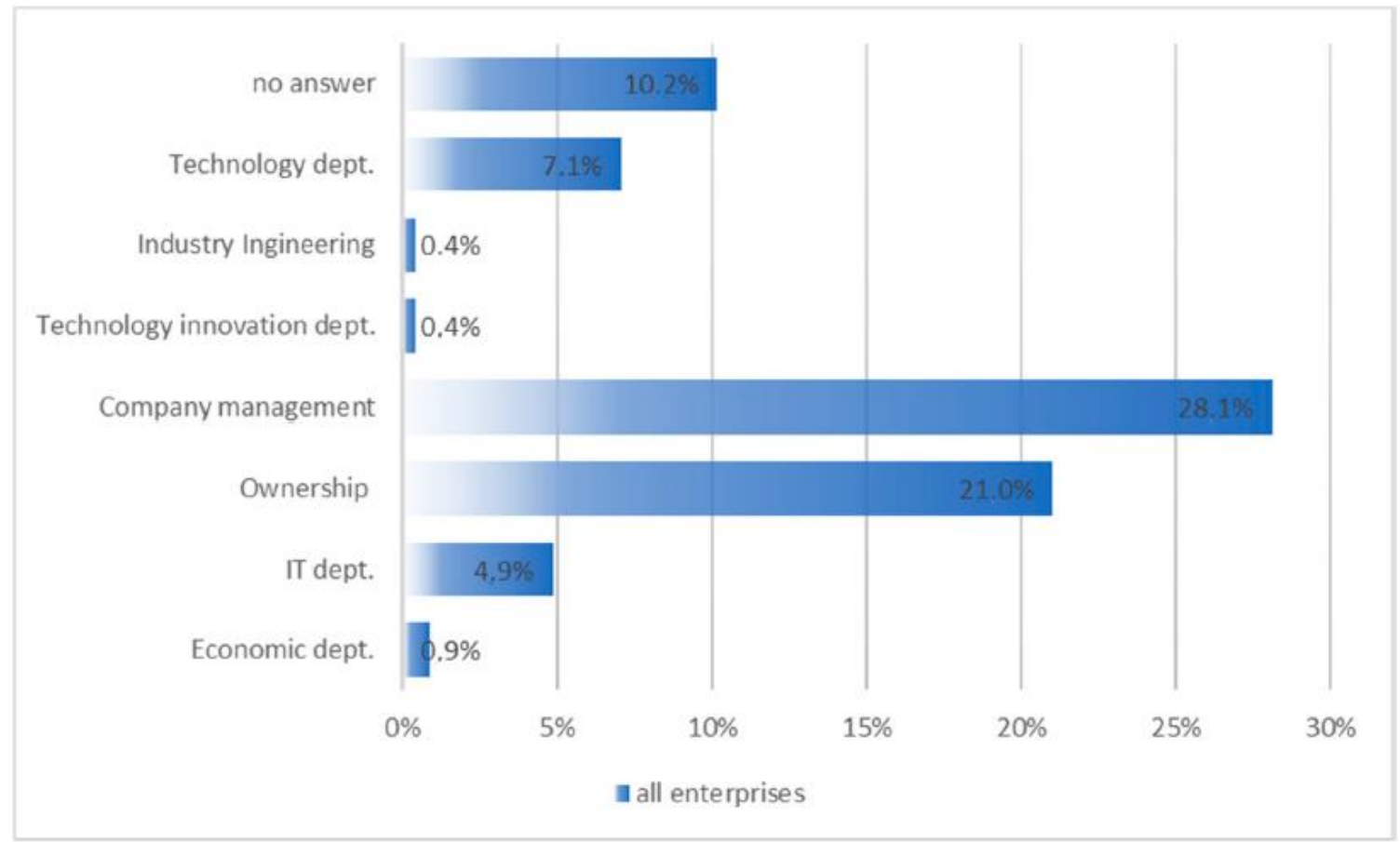

Figure 3. Departments of the company dealing with the Industry 4.0 elements implementation.

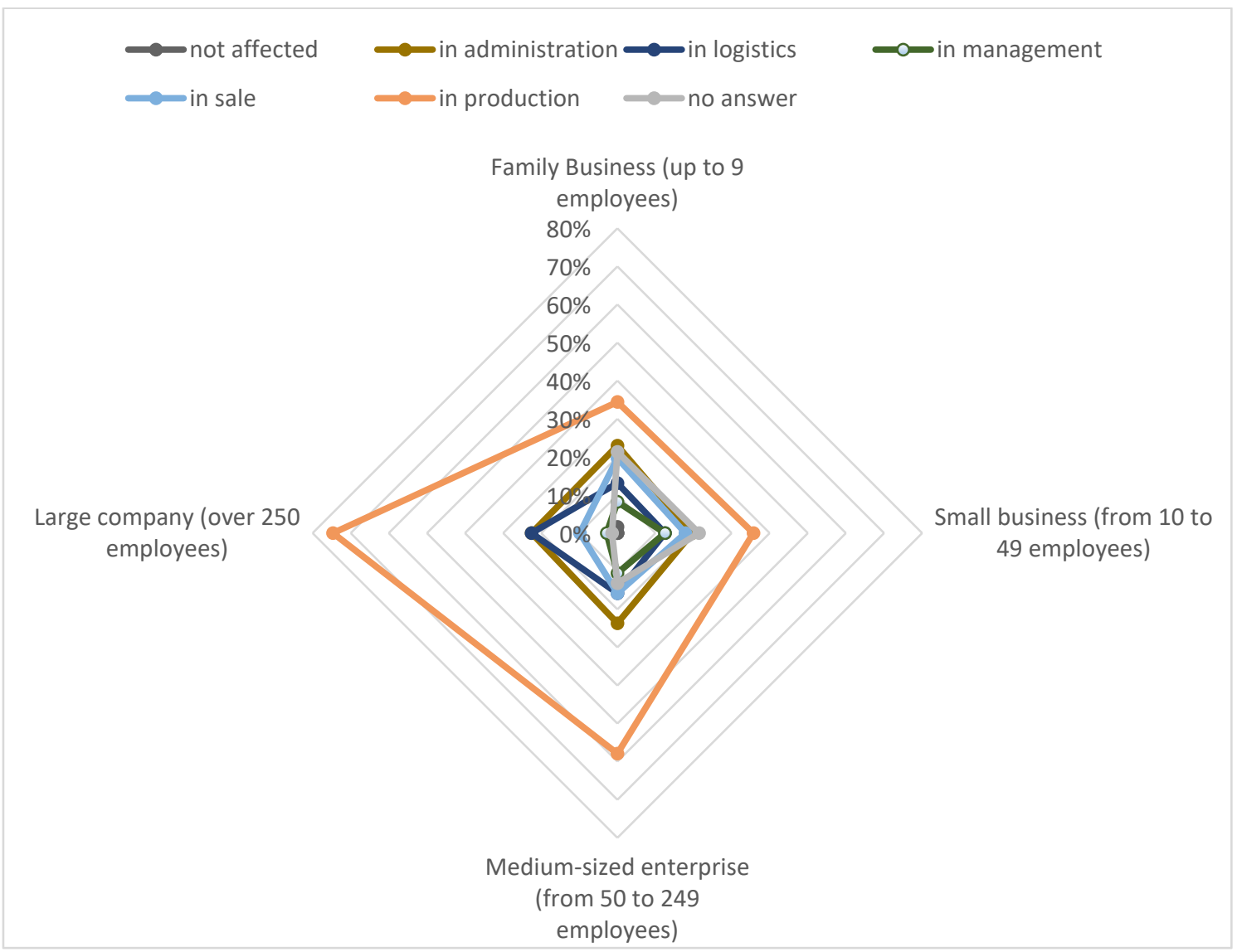

Figure 4. Areas where Industry 4.0 concept would affect the number of employees. 
The next phase of the research was focused on the reasons regarding the implementation of Industry 4.0 in companies according to the size of companies, so the assessment object was the question: What is the main reason to implement the smart industry elements in your company? The results are illustrated in Figure 5. The findings show that the most common reasons for implementing the Industry 4.0 concept are to increase labor productivity, increase the quality of products or services, and the lack of labor. Among the expected benefits for companies, in the questionnaire survey, the opinion of companies on solving problems with a shortage of workers in relation to Industry 4.0 was mainly observed. According to the industry companies surveyed, the implementation of Industry 4.0 was not a primary issue to resolve the shortage of staff.

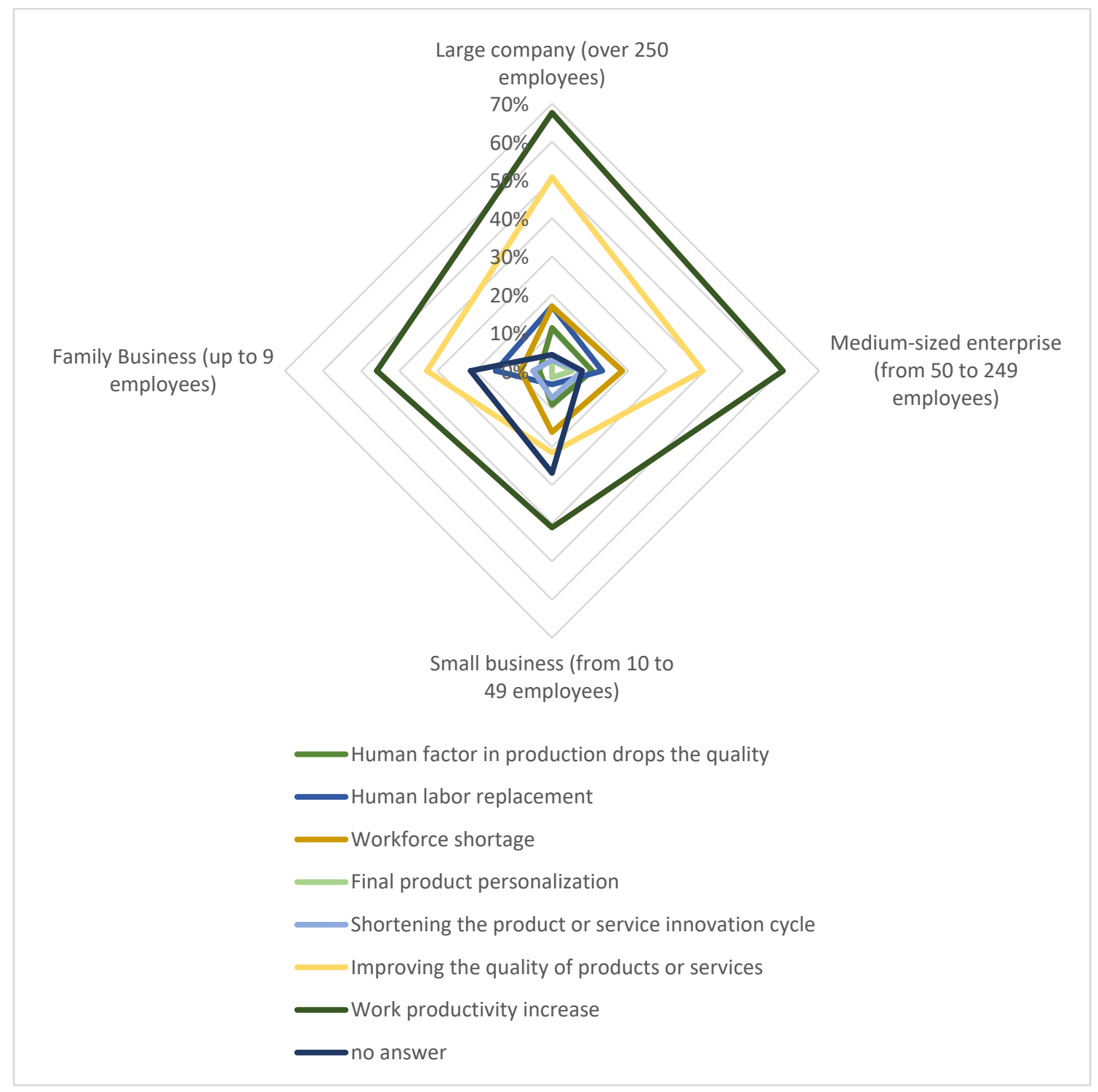

Figure 5. Reasons to implement the Industry 4.0 concept in enterprises by size of enterprise.

However, not all companies are identified with the smart industry elements implementation process, so there was also an issue in terms of the reasons not to implement these elements. This fact is reflected in Figure 6. The following question was analyzed-what is the main reason for not implementing the smart industry elements in organization. 


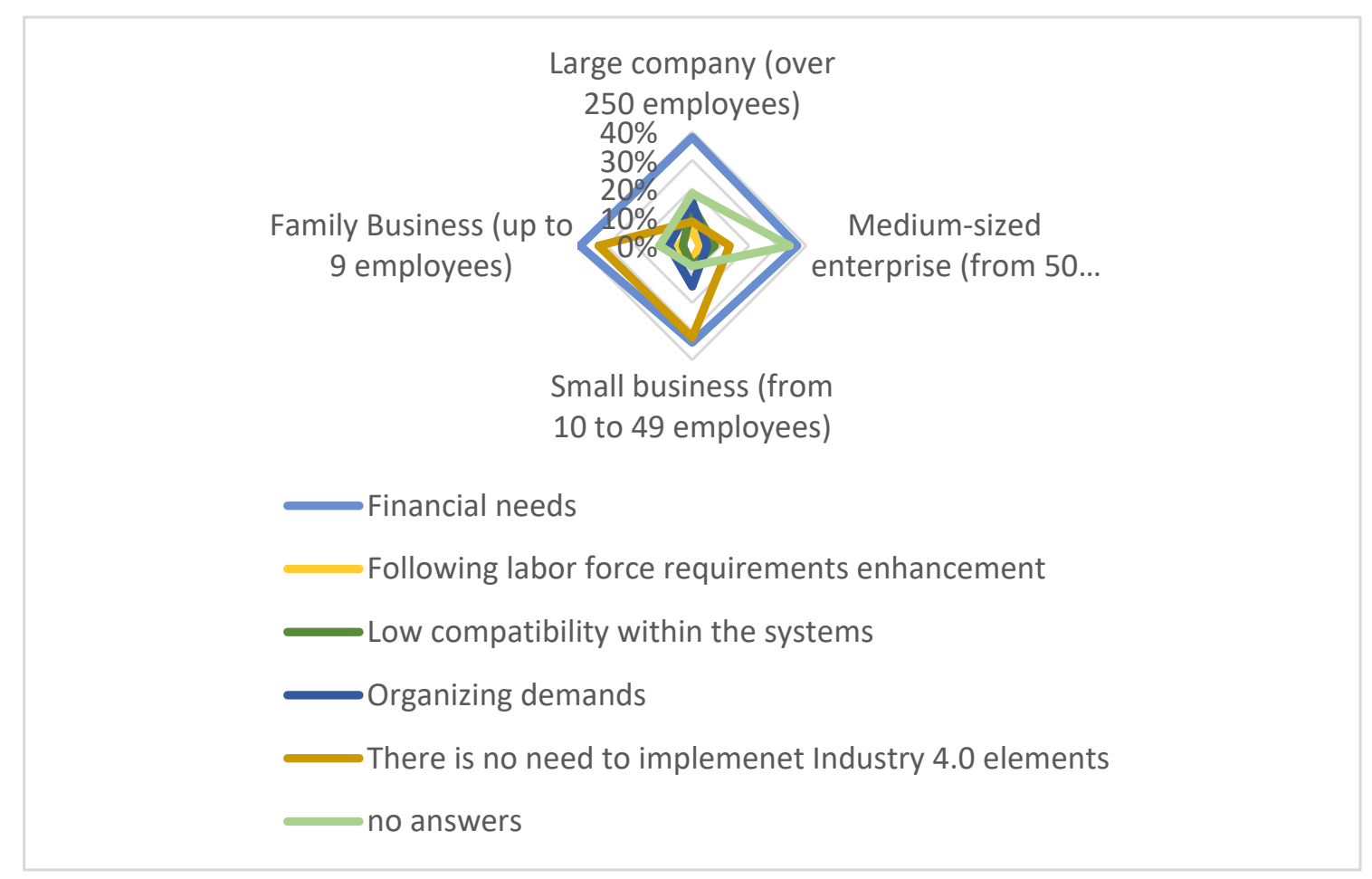

Figure 6. Reasons not to implement the Industry 4.0 concept in enterprises by size of enterprise.

The findings clearly show that the most common reasons for not implementing the smart industry elements are the financial needs and companies do not yet feel the need to implement these elements. However, with this approach there is a threat, that those companies would significantly lose market flexibility and competitiveness. The current situation in the world (April 2020) significantly affects the operation of all companies and it turns out that the economic crisis caused by the coronary virus global pandemic outbreak will significantly accelerate the smart industry elements implementation processes in all spheres of a society, not only in business. Contact with the customer as well as delivery of goods is changing significantly, hence the flexibility of companies. Companies that have been involved in implementing these elements will clearly have a competitive advantage.

The way and education focus will significantly affect the preparation of workforce for the needs of employers, it is well known that the education system in its current form is not flexible enough to adapt to the labor market needs. Therefore, in the next part, the research was focused on the area that should be affected by the content of education from the point of view of employers (Figure 7), the question for respondents was stated as "New content of education in connection with Industry 4.0, should refer to ..."

The answers presented in Figure 7 show that employers demand mainly technical skills and field specialization, which is very debatable, because the content of future job creation is not known yet, so in our opinion it will be far more important to be focused on general knowledge and training in specializations will be more shifted to employers. It is expected that there will be many more specializations than usual and it will not be possible to meet these requirements in formal education system. Quite strongly, the survey points to the need to support education in communication skills and teamwork. The following graphs show the answers regarding the company size. This issue must also be analyzed in terms of company size because of a more detailed analysis of family businesses. Therefore, the following graph (Figure 8) shows the answers according to the size of enterprises. 


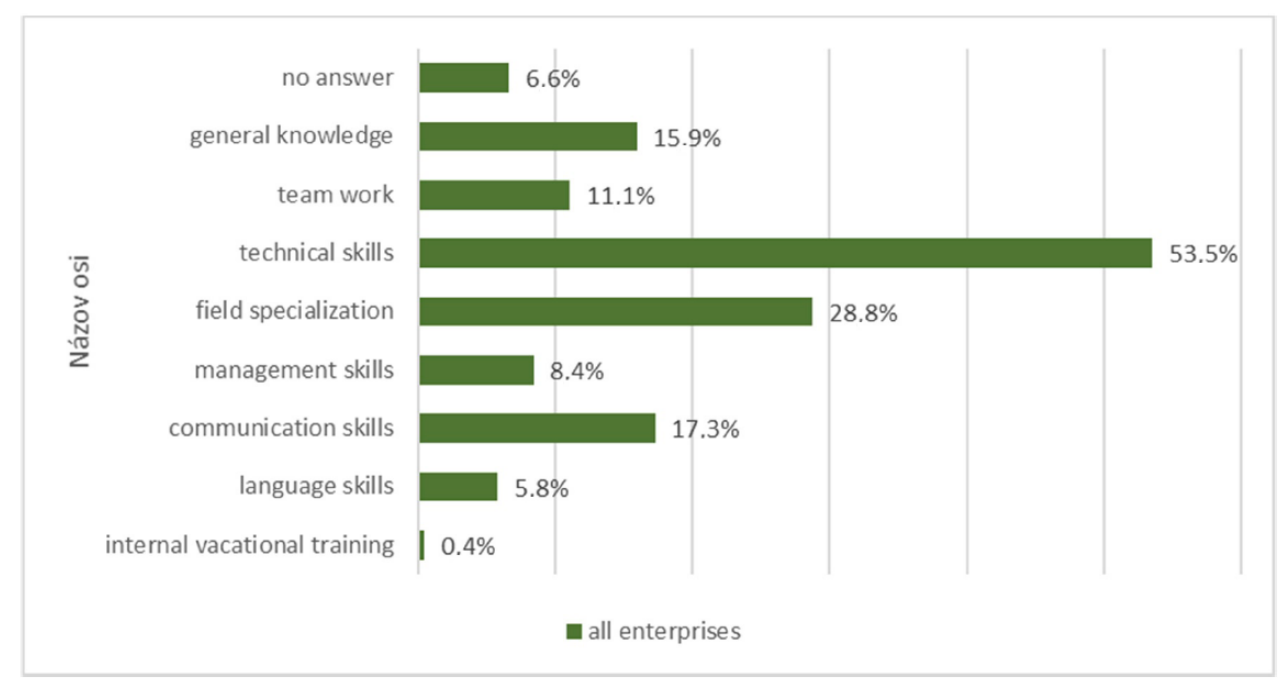

Figure 7. Education focus with respect to Industry 4.0.

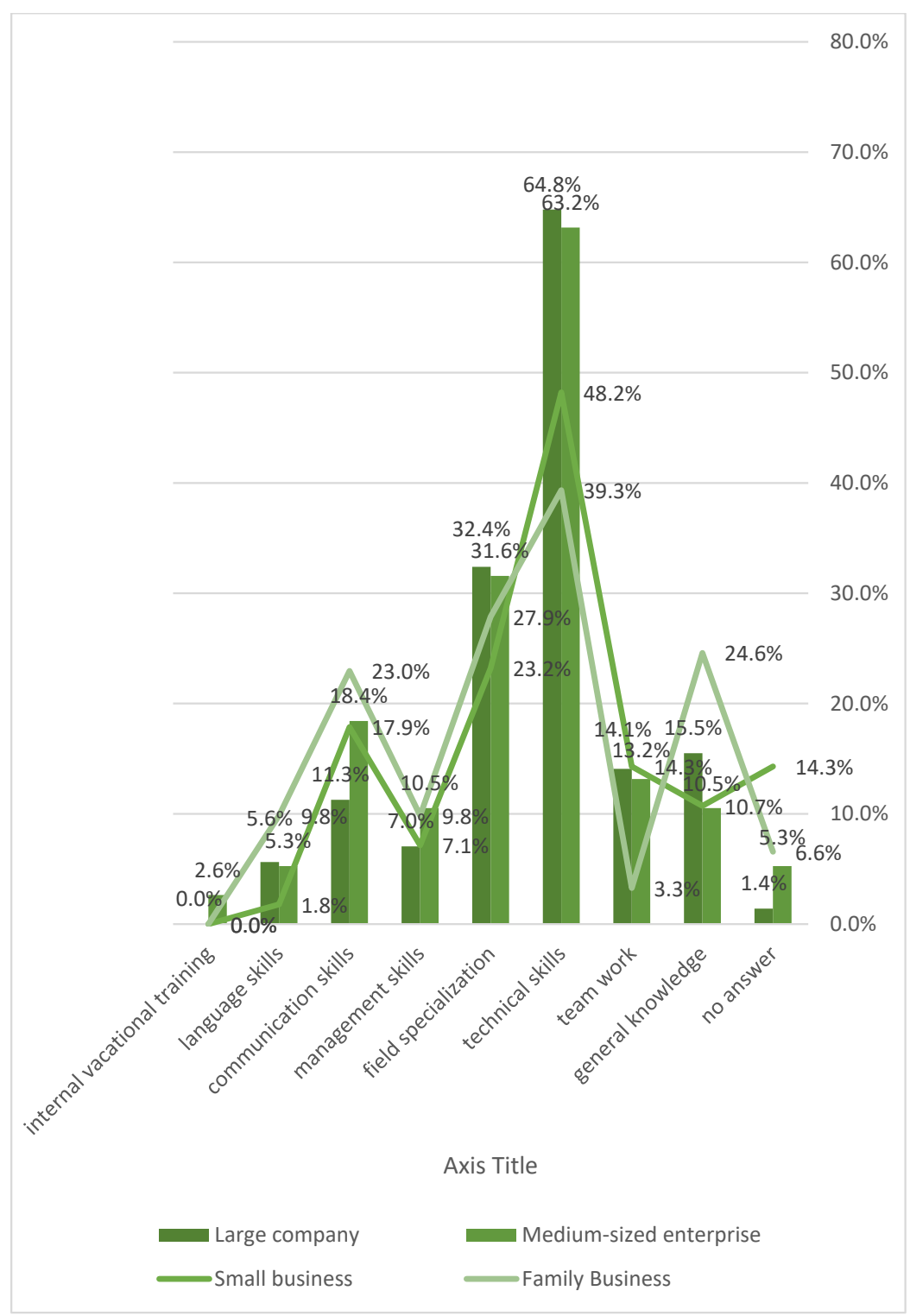

Figure 8. Education focus proposal—by size of enterprise. 
From the questionnaire survey results presented in Figure 8, it can be concluded that, as expected, the size of the company affects the training requirements. Small and medium-sized companies also prefer technical skills, but prefer a general knowledge by contrast to large companies. The employee in a small and medium-sized company must be more flexible and therefore such a content of education can be more beneficial. Interestingly, internal vocational training is not preferred at all. However, employers will have to redirect the human resources departments far more to train their employees, it will be specific knowledge and skills that will not be possible to learn in formal education system.

\section{Discussion}

Based on the displayed results it can be discussed that the impact of Industry 4.0 is currently significantly beginning to be distinctive not only in manufacturing sector but also in other areas of society. The Covid 19 pandemic outbreak has significantly accelerated the use of new technologies in health care and public and state administration sectors. This has been reveled in areas that would have been waiting for this shift for several years, especially in the areas of trade, services, education, healthcare and others. These rapid changes will have a significant impact on job creation, but it is relatively difficult to predict the extent to which this will happen. Many jobs will be lost, but at the same time new types of jobs will be created. Most jobs will go through job redesign, and in this context, the requirements for the workforce in relation to their knowledge and skills will also change. The basis on which this change towards a smart industry can take place is a change in education, not for the needs of the current industry, but for the needs of the future types of industry sectors.

From the research results it can be noticed that academics, CEOs and executives have their firm but different perspectives on discussion, as do employment policy makers. The research shows that the implementation of Industry 4.0 concept evokes significant changes in industry and labor market. The question is whether this change will give rise to, above all, a massive outflow of workers or the creation of new job opportunities. Without current urgent and targeted measures to manage the short-term transition and workforce with skills for the future, national governments will have to face growing unemployment and social inequality, as well as businesses with a shrinking consumer base. In Slovakia, the area of the automotive industry dominates in industrial enterprises and the transformation processes in this area will have the greatest impact on the changes, which will, last but not least, affect the structure of jobs. Even today, industrial companies are facing labor shortages at all. In this context, even the workforce that is free and available on labor market is no longer in a qualitative structure that meets the requirements of employers in a company. At present, companies feel a shortage of professionals, regardless of their level of education, especially in technical fields, but especially in complete secondary and higher education. Other most sought-after workers in the industrial sector include graduates from universities with major in computer science, where every other company is looking for such a worker. Industrial companies are also largely looking for employees without an emphasis on the field of education, which points out to two important facts. One is an absolute shortage of manpower and the other is the ability of companies to train workers from other departments to suit the position they are looking for.

Slovak authors such as Modrak et al. (2019), Modrak and Zuzana (2020) and Židek et al. (2020) also are dealing with the issue of Industry 4.0, Innovation and SME. They have discovered that, the significant problem in the usability of clouds platforms is the lack of support to store a digital twin and its simulation and visualization. Industry 4.0 uses both technologies: cloud platforms for simple data storage, and digital twins for actual status visualization and simulation. Therefore, there is a need to have some connection between these technologies. They also figured out that, in the digital, narrowly specialized and advanced globalized era, meaningfulness of value-creating activities is important for the future of the business. Currently, the companies consider meaningfulness of work and communication as the most important values of people management. The research results presented in papers of Slovak authors and in our paper in similar way describe the value profiling of 
companies operating in Slovakia and the values the companies consider crucial for the success of their business in the Industry 4.0 era.

By and large, based on today's knowledge of Industry 4.0 as the next stage of technical revolution, it can be stated that, from the previous ones, this one will be the fastest implemented industrial revolution we have seen so far. This phenomenon would not affect only production lines, but will change the way society operates. Not only business processes will be affected, but also the way in which communication between employees and employers, customers and manufacturers, or service providers will take place. Due to the speed and complexity of the changes brought about by the Fourth Industrial Revolution, it will be necessary to respond adequately flexibly to this challenge. The responsibility for implementing Industry 4.0 into the company's strategy is in most cases taken over by the top management, and this is a sign that these are key changes. Businesses are implementing the elements of smart industry primarily into production processes. These changes will also make changes in other areas, such as the company's logistics system and the supply chain connected to it. At last, the implementation of a smart industry will not avoid the area of communication with customer and any many administrative activities.

Generally speaking, it can be assumed that recognizing the necessity and benefits from implementing the Industry 4.0 concept, industrial enterprises are willing and able to intensively participate and cooperate in training and retraining of workers to be prepared for challenges regarding smart industry in a suitable labor educational structure. The view of the current education system by companies is critical, they see it as untailored to the Industry 4.0 challenges. The school system currently produces a shortage of graduates with technical education who are most in demand on labor market. However, Industry 4.0 has been creating new jobs for several years, and people are already being employed in positions that did not exist ten years ago. The smart industry will undoubtedly bring revolutionary changes in understanding the society, ways of communication and jobs structure. However, it will also bring a number of new opportunities and it is a must for governments and businesses to cooperate to be prepared for these challenges the best.

\section{Conclusions}

Considering the research results, it can be concluded that only a tenth of industrial enterprises in Slovakia are not familiarized with the issue of Industry 4.0 or do not deal with it. Other companies are analyzing the possibilities of smart industry elements implementation into their processes, or are implementing them directly to a greater or lesser extent. Industrial companies especially SMEs in Slovakia see the greatest benefits from intelligent industry implementation. The main advantage can be seen in increasing the efficiency of production processes and also improving the flow of information within the company. As a significant synergy from being involved in the issue of Industry 4.0, companies also expect a reduction in production and operating costs.

To summarize the results of the research, companies expect an increase in production efficiency from the introduction of the intelligent industry, and see the shortage of workers as a much more complex problem that will not be solved primarily by the implementation of Industry 4.0. With the appearance of Industry 4.0 within industrial enterprises, the issue of job structure will become increasingly urgent. The research has shown that companies will focus on the professionalism of employees to be able to cope with new technologies as best they can. For these workers, there is no reason to worry about finding a job on the labor market in the future. The impact on jobs will also vary depending on the size of the companies, while small companies expect employment to be maintained, medium-sized and especially large companies will be cutting jobs, especially from the ranks of the working professions, without employment in the field of study.

To broaden the topic, the further research will continue with exploring the role of Industry 4.0 and its impact on labor market development within the world economy, particularly in the U.S. and EU economies. Regarding the COVID global pandemic outbreak issue within the Industry 4.0 the smart quarantine is to be a crucial issue. That's why our next research will also deal with the implementing 
of smart quarantine in Slovakia. As research limitation it can be mentioned that some questioners from the survey had to be void and some answers were not relevant. The set of companies, which were the subject of the research, is a limiting factor. The selection of companies based on their regional operation, size and business sector does not correspond to the structure of companies in all of Slovakia. Slovakia is specific for its automotive industry focus, having the greatest number of cars produced per capita in Europe. Therefore, the responses of large companies in the sample reflect the automotive industry.

Author Contributions: Conceptualization, A.G. and M.K.; methodology, A.G.; software, V.B.; validation, A.G., M.K. and V.B.; formal analysis, A.G. and M.K.; investigation, A.G.; resources, M.K.; data curation, A.G. and V.B.; writing—original draft preparation, A.G. and M.K.; writing—review and editing, M.K.; visualization, M.K. and V.B.; supervision, A.G.; project administration, A.G. and M.K.; funding acquisition, A.G. and M.K. All authors have read and agreed to the published version of the manuscript.

Funding: This paper was supported by the Slovak Ministry of Education's Scientific grant agency VEGA: "The impact of Industry 4.0 on jobs structure changes". Project registration number: [Reg. No.: 1/0430/18]. This paper was supported by the Slovak Ministry of Education's Scientific grant agency VEGA: "Assessment changes in the qualitative structure of international economic relations under the influence of Industry 4.0 with implications for the EU and Slovak economic policies". Project registration number: [Reg. No.: 1/0462/20].

Conflicts of Interest: The authors declare no conflict of interest. The funders had no role in the design of the study; in the collection, analyses, or interpretation of data; in the writing of the manuscript, or in the decision to publish the results.

\section{References}

Belas, Jaroslav, Gavurova Beata, Cepel Martin, and Kubak Matus. 2020. Evaluation of economic potential of business environment development by comparing sector differences: Perspective of SMEs in the Czech Republic and Slovakia. Oeconomia Copernicana 11: 135-59. [CrossRef]

Blštáková, Jana, Joniaková Zuzana, Jankelová Nadežda, Stachová Katarína, and Stacho Zdenko. 2020. Reflection of Digitalization on Business Values: The Results of Examining Values of People Management in a Digital Age. Sustainability 12: 5202. [CrossRef]

Bolotov, Ilya, and Josef Tauser. 2015. Dependence of Czech Exports on German GDP-A Structural Analysis. In Small States-Big Challenges: The Experience of the EU and Visegrad Region. Prague: Univ Econ Prague, pp. $97-112$.

Boukalova, Katerina, Kolarova Alena, and Lostak Michal. 2016. Tracing shift in Czech rural development paradigm (Reflections of Local Action Groups in the media). Agricultural Economics-Zemedelska Ekonomika 62: 149-59. [CrossRef]

Cajka, Radek, Kral Petr, and Tauser Josef. 2015. International Scientific Conference: "Central and Eastern Europe in the Changing Business Environment". Politicke Vedy 18: 278-81.

Cernohlavkova, Eva, Machkova Hana, Sterbova Ludmila, and Zadrazilova Dana. 2013. Foreign and Domestic Trade-The History and Development of Science Branch. Politicka Ekonomie 61: 407-19. [CrossRef]

Cihelkova, Eva, and Nguyen Phuoc Nguyen. 2018. EU's and China's Approaches to Adapting Mutual Relations to New Global Conditions. In PTS 1-3 Book Series: International Conference on European Integration, Paper presented at the 4th International Conference on European Integration 2018 (ICEI 2018), Ostrava, Czech Republic, May 17-18. Ostrava: VSB Techn Univ Ostrava, pp. 190-98.

Cihelkova, Eva, Nguyen Phuoc Nguyen, Fabus Michal, and Cimova Kristina. 2020. The EU Concept of the "Strategic Partnership": Identifying the "Unifying" Criteria for the Differentiation of Strategic Partners. Entrepreneurship and Sustainability Issues 7: 1723-40. [CrossRef]

Daňo, Ferdinand, and Dagmar Lesáková. 2018. The role of environmental stimuli in shopping evaluation and responses. Ekonomicky Casopis 66: 465-78.

Di Nardo, Mario, Forino Daniel, and Murino Teresa. 2020a. The evolution of man-machine interaction: The role of human in Industry 4.0 paradigm. Production \& Manufacturing Research 8: 20-34. [CrossRef]

Di Nardo, Mario, Madonna Marianna, Murino Teresa, and Castagna Francesco. 2020b. Modelling a Safety Management System Using System Dynamics at the Bhopal Incident. Applied Sciences 10: 903. [CrossRef]

Drabik, Peter, and Peter Zamecnik. 2016. Key Aspects of Logistics for Online Store and Multi-channel Distribution. In Proceedings of 16th International Joint Conference: Central and Eastern Europe in the Changing Business Environment. Prague: Univ Econ Prague, pp. 97-111. 
Dudáš, Tomáš, and Martin Grančay. 2019. Regional structure of foreign direct investment in Slovakia-A district-level gravity-type model 2009-2016. Ekonomicky Casopis 67: 811-36.

Eurostat. 2020. Available online: https://eurostat.sk (accessed on 17 March 2020).

Fojtikova, Lenka. 2018. China's Intellectual Property Rights Commitments in the WTO: Legal and Economic Implications. China and WTO Review 4: 7-34. [CrossRef]

Fojtikova, Lenka, and Michaela Stanickova. 2017. The EU member states export competitiveness and productivity. Politicka Ekonomie 65: 669-89. [CrossRef]

Fraga-Lamas, Paula, Tiago M. Fernández-Caramés, and Castedo Luis. 2017. Towards the Internet of Smart Trains: A Review on Industrial IoT-Connected Railways. Sensors 17: 1457. [CrossRef] [PubMed]

Grmelova, Nicole. 2018a. The CJEU Elaborates on The Concept of Consumers with Respect to International Jurisdiction for Class Actions. Paper Presented at 16th International Conference Economic Policy in The European Union Member Countries, Celadna, Czech Republic, 12-14 September 2018; pp. 107-13.

Grmelova, Nicole. 2018b. Awarding Damages for Health Impairment in Recent Case Law of the Court of Justice of the EU. In PTS 1-3 Book Series: International Conference on European Integration, Paper presented at International Conference on European Integration 2018 (ICEI 2018), Ostrava, Czech Republic, Jun 22-May 18, 2011-2018. Ostrava: VSB Techn Univ Ostrava, pp. 349-55.

Hanulakova, Eva, and Ferdinand Dano. 2018. Circular Economy as a New Managerial Approach. AD ALTA-Journal of Interdisciplinary Research 8: 95-98.

Hanulakova, Eva, Ferdinand Dano, and Peter Drabik. 2019. Approaches to Education in the Field of Management, Marketing and Environmental Consulting. AD Alta-Journal of Interdisciplinary Research 9: 84-91.

Harakal'ova, Lubica. 2018. The Concept of Smart Villages (Smart Places) in EU Policies. In International Relations 2018: Current Issues of World Economy and Politics. Bratislava: Vydavatelstvo Ekonom, pp. 221-26.

Haviernikova, Katarina, and Eva Ivanova. 2018. Evaluation of Selected Risk Categories Related to Marketing Activities by SMEs in Case of Potential Cluster Cooperation. In Book Series: AEBMR-Advances in Economics Business and Management Research, Paper presented at Third International Conference on Economic and Business Management (FEBM 2018), Hohhot, China, October 20-22. Paris: Atlantis Press, vol. 56, pp. 433-36.

Haviernikova, Katarina, and Jozef Klucka. 2019. The Risks in the Case of Cluster Cooperation and Ways of their Prevention: As Seen by SMEs Entrepreneurs. AD ALTA-Journal of Interdisciplinary Research 9: 114-19.

Helisek, Mojmir. 2015. Perspectives of the Accession of the Czech Republic to the Euro Area in terms of the Price Level Convergence. Economics \& Sociology 8: 28-35. [CrossRef]

Helisek, Mojmir. 2018. The Risks Associated with The "Danish Scenario" for the Participation of the Czech Koruna in the ERM II. Paper Presented at 16th International Conference Economic Policy in the European Union Member Countries, Celadna, Czech Republic, 12-14 September 2018; pp. 139-49.

Hnat, Pavel, and Ondrej Sankot. 2019. European imbalances and shifts of global value chains to the Central European periphery: Role of institutions. AUC Geographica 54: 221-31. [CrossRef]

Hnat, Pavel, and Zuzana Stuchlikova. 2014. China-V4 Investment Relations-A Czech Perspective. In Current Trends and Perspectives in Development of China-V4 Trade and Investment. Bratislava: Vydavatelstvo Ekonom, pp. 61-81.

Ivanová, Eva, and Jana Masárová. 2018. Performance evaluation of the Visegrad Group countries. Economic Research-Ekonomska Istrazivanja 31: 270-89. [CrossRef]

Jašková, Dana. 2019. Assessment of social development in Slovakia in the context of human resources. Central European Journal of Labour Law and Personnel Management 2: 21-32. [CrossRef]

Jirankova, Martina. 2012. Nation-States as Investors in a Globalized World. Ekonomicky Casopis 60: 854-70.

Jirankova, Martina, and Pavel Hnat. 2012. Balance of payments adjustment mechanisms in the Euro area. Eastern Journal of European Studies 3: 67-86.

Jirankova, Martina, Hnat Pavel, Antal Jarolim, and Sankot Oondrej. 2015. Euro Area Imbalances-Macroeconomic Competitiveness as a Balancing Factor? In Small States—Big Challenges: The Experience of the EU and Visegrad Region. Prague: Oeconomica, pp. 9-25.

Kiselyova, Elena. 2020. Labor compliance as an instrument of labor relations control. Central European Journal of Labour Law and Personnel Management 3: 21-32. [CrossRef]

Krajnakova, Emilia, and Sergej Vojtovic. 2017. Struggles of Older Workers at the Labour Market. Economics $\mathcal{E}$ Sociology 10: 319-33. [CrossRef] 
Krajnakova, Emilia, Jegelaviciute Rusne, and Navickas Valentinas. 2018a. The Economic Factors Influence on Real Estate Market Development. AD ALTA-Journal of Interdisciplinary Research 8: 141-46.

Krajnakova, Emilia, Navickas Valentinas, and Kontautiene Rima. 2018b. Effect of macroeconomic business environment on the development of corporate social responsibility in Baltic Countries and Slovakia. Oeconomia Copernicana 9: 477-92. [CrossRef]

Kreckova, Zuzana, Odehnalova Jitka, and Reardon James. 2012. Consumer Ethnocentricity within the Environment of Economic Crisis. Inzinerine Ekonomika-Engineering Economics 23: 271-81. [CrossRef]

Kreckova, Zuzana, Zadrazilova Dana, and Rezankova Hana. 2016. The Added Value of Women in Management: The Czech Case. Prague Economic Papers 25: 354-73. [CrossRef]

Krnacova, Paulina, and Peter Drabik. 2018. Consumer Awareness about Electromobility. Paper Presented at 18th International Joint Conference: Central and Eastern Europe in the Changing Business Environment, Bratislava, Slovakia, 5-25 May 2018; pp. 190-201.

Lipkova, Ludmila. 2017. New Time in the Development of the Republic of Chinese. In International Relations 2017: Current Issues of World Economy and Politics. Bratislava: Vydavatelstvo Ekonom, pp. 684-91.

Lipkova, Ludmila, and Katarina Hovorkova. 2018. Economic situation in Norway after the outbreak of the global financial and oil crises in the context of EU integration trends. Economic Annals-XXI 169: 12-14. [CrossRef]

Lipkova, Ludmila, Gress Martin, and Poncarova Alena. 2017. Tax systems in the Czech Republic and the Slovak Republic: Comparison with an emphasis on income tax. Economic Annals-XXI 165: 47-51. [CrossRef]

Ližbetinová, Lenka, Štarchoň Peter, Weberová Dagmar, Nedeliaková Eva, and Juříková Martina. 2020. The Approach of SMEs to Using the Customer Databases and CRM: Empirical Study in the Slovak Republic. Sustainability 12: 227. [CrossRef]

Machkova, Hana. 2013. Sugar Industry in France. Listy Cukrovarnicke a Reparske 129: 356-58.

Machkova, Hana, and Alexej Sato. 2017. Analysis of Competitiveness of Belgian Sugar Industry. Listy Cukrovarnicke a Reparske 133: 390-92.

Maitah, Mansoor, and Lubos Smutka. 2019. Development of World Sugar Prices. Sugar Tech 21: 1-8. [CrossRef]

MH SR-Ministry of Economy of Slovak Republic. 2020. Available online: https://economy.gov.sk (accessed on 17 March 2020).

Miklosik, Andrej, Kuchta Martin, and Zak Stefan. 2018. Monetising Content through Delivery of Advertisements: The Case of Ad Blockers. Ad Alta-Journal of Interdisciplinary Research 8: 175-79.

Miklosik, Andrej, Evans Nina, Zak Stefan, and Lipianska Julia. 2019a. A framework for constructing optimisation models to increase the visibility of organizations' information in search engines. Information Research-An International Electronic Journal 24: 808.

Miklosik, Andrej, Kuchta Martin, Evans Nina, and Zak Stefan. 2019b. Towards the Adoption of Machine Learning-Based Analytical Tools in Digital Marketing. IEEE Access 7: 85705-18. [CrossRef]

Modrak, Vladimir, and Soltysova Zuzana. 2020. Management of Product Configuration Conflicts to Increase the Sustainability of Mass Customization. Sustainability 12: 3610. [CrossRef]

Modrak, Vladimir, Soltysova Zuzana, and Onofrejova Daniela. 2019. Complexity Assessment of Assembly Supply Chains from the Sustainability Viewpoint. Sustainability 11: 7156. [CrossRef]

Mura, Ladislav. 2019. Entrepreneurship Internationalization-Case of Slovak Family Businesses. AD Alta-Journal of Interdisciplinary Research 9: 222-26.

Mura, Ladislav, and Aleksandr Kljucnikov. 2018. Small Businesses in Rural Tourism and Agrotourism: Study from Slovakia. Economics E Sociology 11: 286-300.

Mura, Ladislav, Havierniková Katarina, and Machová Renata. 2017. Empirical results of entrepreneurs' network: Case study of Slovakia. Serbian Journal of Management 12: 121-31. [CrossRef]

Nenckova, Lucie, Pecakova Iva, and Sauer Petr. 2020. Disposal behaviour of Czech consumers towards textile products. Waste Management 106: 71-76. [CrossRef]

Nevima, Jan, Tureckova Kamila, and Varadzin Frantisek. 2018. The Role of Public Administration Bodies in Relation to the Unsuccessful Drawing Funds from the European Union in the Sphere of Education. Paper Presented at 16th International Conference Economic Policy in the European Union Member Countries, Celadna, Czech Republic, 12-14 September 2018; pp. 251-58.

OECD. 2020. Available online: https://www.oecd-ilibrary.org/ (accessed on 23 January 2020). 
Okreglicka, Malgorzata, Haviernikova Katarina, Mynarzova Monika, and Lemanska-Majdzik Anna. 2017. Entrepreneurial Intention Creation of Students in Poland, Slovakia and Czechia. Polish Journal of Management Studies 15: 162-72. [CrossRef]

Sadilek, Tomas, and Dana Zadrazilova. 2015. History and Nowadays Situation of Sugar Industry in Austria. Listy Cukrovarnicke a Reparske 131: 392-95.

Sadilek, Toms, and Dana Zadrazilova. 2016. Current Trends in German Sugar Industry. Listy Cukrovarnicke a Reparske 132: 390-93.

Salama, Ahmed, and Judit Oláh. 2019. Key factors affecting unemployment in the Arab world. Central European Journal of Labour Law and Personnel Management 2: 60-72. [CrossRef]

Saroch, Stanislav. 2015. European crossroads. Politicka Ekonomie 63: 677-80. [CrossRef]

Saroch, Stanislav, and Jan Famfule. 2016. The Strengths and the Bottlenecks of the European Banking Union. Paper Presented at 14th International Scientific Conference: Economic Policy in the European Union Member Countries, PTS 1 and 2, Petrovice Karvine, Czech Republic, 14-16 September 2016; pp. 717-27.

Saroch, Stanislav, and Vaclav Smejkal. 2018. Rethinking the EU Globalization Policies. Available online: https: //is.muni.cz/publication/1459476/ICEI-2018_Proceedings.pdf\#page=1458 (accessed on 9 September 2020).

Sauer, Petr, Hadrabova Alena, and Kreuz Jaroslav. 2018. Decoupling of GDP and air pollution in the Czech Republic: Trend analysis and policy story behind. International Journal of Environmental Technology and Management 21: 253-72. [CrossRef]

Sauer, Petr, Kolinsky Oondrej, and Prasek Jan. 2019. Negotiating Municipalities-Industrial Factory Wastewater Treatment Coalition Project: An Economic Laboratory Experiment. Journal of Environmental Protection and Ecology 20: 369-75.

Sejkora, Jiri. 2014. Poor Economics: A Radical Rethinking of the Way to Fight Global Poverty. Ekonomicky Casopis 62: 431-35.

Sejkora, Jiri, and Ondrej Sankot. 2017. Comparative advantage, economic structure and growth: The case of Senegal. South African Journal of Economic and Management Sciences 20: a1685. [CrossRef]

Simionescu, Mihaela, Bilan Yurij, and Streimikiene Dalia. 2019. The Impact of Biodiesel Consumption by Transport on Economic Growth in the European Union. Inzinerine Ekonomika-Engineering Economics 30: 50-58. [CrossRef]

Stachová, Katarína, Stacho Zdenko, Cagáňová Dagmar, and Stareček Augustín. 2020. Use of Digital Technologies for Intensifying Knowledge Sharing. Applied Sciences 10: 4281. [CrossRef]

Svarc, Zbynek, and Nicole Grmelova. 2015. Consumer Protection in Common European Sales Law. Paper Presented at 12th International Scientific Conference: Economic Policy in the European Union Member Countries, PTS I and II, Ostravice, Czech Republic, 16-18 September 2014; pp. 820-28.

Tajtakova, Maria, Zak Stefan, and Filo Peter. 2019. The Lipstick Effect and Outdoor Cultural Consumption in Slovakia in Times of Crisis. Ekonomicky Casopis 67: 607-28.

Tauser, Josef, Zambersky Pavel, and Cajka Radek. 2013. Comparative price levels of new EU member countries. International Journal of Management and Economics 39: 9-17. [CrossRef]

Toth, Daniel, Maitah Mansoor, and Maitah Kamil. 2019. Development and Forecast of Employment in Forestry in the Czech Republic. Sustainability 11: 6901. [CrossRef]

Tupa, Magdalena, and Sergej Vojtovic. 2018. Impact of Brexit on the Migration in the UK. AD ALTA-Journal of Interdisciplinary Research 8: 306-9.

Varadzin, Frantisek. 2016. Global Public Goods and Integration. Paper presented at 3rd International Conference on European Integration 2016 (ICEI 2016), Ostrava, Czech Republic, 19-20 May 2016; pp. 1052-59.

Zadrazilova, Dana. 2013. Sustainable Business. Motivating Business Leaders to Social Responsible Behaviour. In Changes in Governance: In the Context of the Global Crisis. Prague: Univ Econ Prague, pp. 189-203.

Zagata, Lukas, Lostak Michal, and Swain Nigel. 2019. Family Farm Succession of the First Post-Socialist Generation in the Czech Republic. Eastern European Countryside 25: 9-35. [CrossRef]

Zagata, Lukas, Hrabak Jiri, and Lostak Michal. 2020. Post-socialist transition as a driving force of the sustainable agriculture: A case study from the Czech Republic. Agroecology and Sustainable Food Systems 44: 238-57. [CrossRef]

Zemanova, Stepanka. 2015. When could new 'potent small states' emerge? A study of the recent metamorphosis of Czech human rights foreign policy. Journal of International Relations and Development 18: 129-54. [CrossRef] 
Zemanova, Stepanka, and Radka Drulakova. 2016. Making Global Goals Local Business in V4 Countries: V4 Entrepreneurs and the UN Global Compact. In Globalization and Its Socio-Economic Consequences, Paper presented at 16th International Scientific Conference Proceedings, PTS I-V, Rajecke Teplice, 5-6 October 2016. Zilina: Univ Zilina, pp. 2490-97.

Zemanova, Stepanka, and Radka Drulakova. 2020. Mainstreaming Global Sustainable Development Goals through the UN Global Compact: The Case of Visegrad Countries. J. Risk Financ. Manag. 13: 41. [CrossRef]

Židek, Kamil, Pitel' Ján, Adámek Milan, Lazorík Peter, and Alexander Hošovský. 2020. Digital Twin of Experimental Smart Manufacturing Assembly System for Industry 4.0 Concept. Sustainability 12: 3658. [CrossRef]

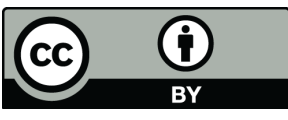

(C) 2020 by the authors. Licensee MDPI, Basel, Switzerland. This article is an open access article distributed under the terms and conditions of the Creative Commons Attribution (CC BY) license (http://creativecommons.org/licenses/by/4.0/). 